\title{
An ethnographic study of Irish Neo-Pagan culture
}

\author{
Jenny Butler \\ Department of Folklore and Ethnology, UCC
}

\section{Introduction}

The idea that Witches and Druids are real people who follow spiritual traditions with serious intent is a hard one to fathom for many people in contemporary society. The neopagan movement is strange and unfamiliar to the general public. Similarly, the research topic of neo-paganism is a relatively new one in academia. The primary aim of my research is to document neo-pagan culture from an ethnographic perspective. There have been very few academic works written on modern or "neo" (new) paganism and, as far as the author is aware at the time of writing, there has been no large-scale ethnographic work at all carried out exclusively on neo-paganism in Ireland, and in this respect the area of research is virgin territory for ethnographic analysis. Ethnography is the documentation and analysis of the culture of a specific group of people in regard to their beliefs, oral traditions (stories, songs and ways of speaking) and ritual practices (symbolic behaviour) and oftentimes their material culture (tangible objects). My research looks at all of these aspects of neo-pagan culture.

\section{What is Neo-Paganism?}

Neo-paganism is an umbrella term used to refer to a variety of spiritual practices. The prefix '-neo' is used to indicate the modern spiritual movement, as distinct from pre-Christian contexts of so-called "pagan" religions. Neo-pagans may choose other labels to describe themselves, such as "earth-based spiritualist" and I include those who self-identify as such, or as "neo-pagan" generically, in my research. Neo-paganism is an umbrella term used to refer to a variety of spiritual practices. The prefix '-neo' is used to indicate the modern spiritual movement, as distinct from pre-Christian contexts of so-called "pagan" religions. Neo-pagans may choose other labels to describe themselves, such as "earth-based spiritualist", and I include those who self-identify as such, or as "neo-pagan" generically, in my research.

One form of neo-pagan spirituality is Druidry. There is also Witchcraft, which itself encompasses an array of paths, including Wicca (a mystical religion), Hereditary Witchcraft 
(passed on through generations of a family) and Traditional Witchcraft or Hedgewitchery (a modern form of witchcraft based on practices associated with the Wise Women figures of pre-modern Ireland, who were generally healers who used herbalism and other traditional means to cure people).

The term Pagan stems from the Latin word paganus, meaning 'country-dweller'. Another neo-pagan path is heathenism, which stems from the Old English word meaning 'inhabiting open country' and is probably the root word for heath or areas of moorland. Both terms are associated with rural areas and the natural landscape and, consequently, neopaganism, a movement that reclaimed the word pagan, has come to be defined as "nature religion". Strictly defining neo-paganism as a religion is problematic. Some neo-pagans, particularly Wiccans, view themselves as priests or priestesses of a mystery religion, since they become a member of clergy on initiation into a Coven (ritual group of witches) while other neo-pagans may feel that it is not a religion at all but a philosophy, or simply their chosen way of life. While many feel that neo-paganism is indeed a religion with its own set of ethical and moral principles, others dislike the label "religion" itself and prefer the term "spiritual"; perhaps this stems from a backlash against organised, dogmatic religions that people were raised with and abandoned in favour of a spirituality that allows people to express themselves freely through ritual and to describe their beliefs in a way that makes sense to them.

\section{Misconceptions}

There are many misunderstandings of what neo-paganism is since the movement has been greatly misconstrued, largely due to its low public profile. The general perception of the average Irish person on hearing the word "pagan" is of a person with no formal religious beliefs, an atheist, or even an individual who holds anti-Christian beliefs. This misapprehension of neo-paganism as anti-Christian most likely stems from the use of the word "pagan" and "heathen" by Christian clerics to mean either something anti-Christian or as evil and Satanic. It is important to clarify that neo-pagans view Satan as part of Christian mythology and, as such, do not acknowledge this figure as a "pagan" deity. The majority of neo-pagans view themselves as followers of the "old religion", i.e., one that pre-dates Christianity and has its own pantheon, distinct from the Christian one.

With Druidry in particular, there seems to be the 'tree-hugging-hippy' stereotype that environmentalists and nature-lovers are often pigeonholed into. The notion of a Druid is often muddled up with the popular image of Merlin of Arthurian legend and wizards of fantasy literature (this is especially the case in the present day with the release of the film trilogy Lord of the Rings, an adaptation of J. R. R. Tolkien's work, which contains the characters of the Wizards Gandalf and Saruman, and also J. K. Rowling's Harry Potter series of books, and the films based on them, which have characters who are wizards). 
There are the more damaging misconceptions of neo-paganism, as when ritual practice is confused with Devil-worship and negative Occult activity; this is largely due to melodramatic films and sensational literature portraying lurid details of "rituals", the Black Mass, brainwashing cults and other tactics intended to shock. Neo-paganism has no connection with such activities, but the fact that some neo-pagans carry out rituals wearing robes and using paraphernalia, which appears strange to those unaccustomed to it, may cause fear if people do not understand what neo-paganism is.

\section{Methodology}

The methodology, or way in which my research was carried out, included two main fieldwork methods: ethnographic interviewing and participant observation. Ethnographic interviewing is an in-depth, conversational style of interviewing, which aims to get insight into "what it is like" to be part of a particular cultural group. Thirty-six interviews were conducted with neo-pagans to find out what it is like to be part of this spiritual community. In my ethnographic description, interview extracts are included so that the interviewee is quoted directly. This is especially important in cases where a person is talking about a strongly held belief or meaningful personal experience, as viewpoints and subjective experiences are better expressed in the words of the interviewee themselves.

Participant observation is a method whereby the researcher takes part in events with the people being researched, so that the academic can gain a better understanding of how life is for the "insider" or member of the cultural group. The researcher is both an insider taking part in the event and also an outsider, in that their role is to analyse what is going on. I took part in different kinds of rituals, seasonal festivals and other kinds of gatherings with various neo-pagan groups.

There are many ethical considerations while conducting this kind of fieldwork. One is to be clear that their role is that of a researcher who is collecting data for academic analysis. It is important to protect the identity of the interviewees and other research participants, which is achieved by the use of pseudonyms. Exceptions are made in cases where the work of pagan artists is discussed or reproduced, as there is an issue with appropriate copyright and credit for this work.

\section{Research question}

My research question is twofold:

(a) What characterises neo-pagan worldview? (b) How is this worldview expressed through ritual behaviour? 
In folkloristics (the academic study of folklore), we use the term "worldview" to mean the belief-system or set of beliefs of a particular cultural group. The study of this is an examination of how certain people view the world. The neo-pagan belief-system can be described as a "magical worldview" because, typically, they believe in magic, spirits and deities. The spiritual practice includes many kinds of rituals, such as life cycle rituals, i.e., baby blessings, Handfastings (neo-pagan term for weddings) and funerals. There are also healing rituals, including the healing of people, animals, and the planet itself or "earth healing". There are also the seasonal festival rituals. Neo-pagans celebrate eight annual festivals: Samhain (October 31st), Winter Solstice (December 21st), Imbolc (February 1st), Spring Equinox (March 21st), Beltaine (May 1st), Summer Solstice (June 21st), Lughnasadh (August 1st) and the Autumn Equinox (September 21st). Some neo-pagans use the Irish-language names for the festivals, but the names are most often found in anglicised form in neo-pagan literature.

\section{Landscape, history and mythology}

My research also looks at identity construction, the process whereby individuals and groups create their own individual worldview or outlook on life, within Irish neo-paganism and what is uniquely Irish about neo-paganism in this country. Some of the cultural resources, or aspects of identity that are held to be important, have to do with the relationship that neo-pagans have with the Irish landscape, mythology and how they perceive history. Neo-pagans have a deep spiritual connection to the natural landscape, which is viewed as a sacred landscape. There is an abiding belief that deities and spirits are placespecific, i.e., geographical areas have their own associated deities and spirits. Many Irish neo-pagans venerate the "old gods" of the land of Ireland and there are those who believe that these gods and goddesses have endured through time and that one can communicate with them today. The "old gods" of Ireland are considered to be those of the Celtic pantheon. Despite the fact that most surviving Celtic legends were recorded after Christianisation, they still contain information about the gods and goddesses of the Celts. For modern Pagans, the legendary characters of Celtic myth are not metaphorical or figurative heroes but real, living, beings that may even have the power to influence the everyday lives of human beings. Neo-pagans honour the deities and sometimes attempt to communicate with them through ritual. For example, one Druidic Grove (a Grove is a ritual group of Druids) named the Owl Grove invokes Lugh during their Lughnasa (Harvest) ritual; Lugh is one of the principal gods of the Celtic pantheon and he is a sun god. Neo-pagans have many sacred sites on the landscape, including Newgrange and the Hill of Tara, which are both in Co. Meath, as well as stone circles and other megalithic monuments and groves of trees. Among neo-pagans, there is a strong affiliation with earliest religions of Ireland and of Europe more generally, and it is often the case that sacred sites are chosen because of their association with earlier and indigenous religious practices. For example, there is 
a connection between religious worship within groves of trees and pre-Christian druids; similarly, megalithic monuments have associations with early religious practices. For the majority of the Irish populace, these are heritage sites with an historical legacy. However, for neo-pagans they are more than just heritage sites and are indeed "living" sites, in that they are used frequently for spiritual purposes, for ritual and as gathering places.

\section{Conclusion}

My analysis of the data I have collected reveals a vibrant and dynamic Irish neo-pagan culture that relates to the Irish landscape, mythology and history in unique ways. I plan to publish my research results in book form, which primarily aims to document aspects of this cultural movement, as it exists in Ireland. A secondary, but important, outcome of publishing this data is that it will lead to a better understanding of this culture both within academia and among the general public. I hope to achieve this by publishing academic articles as well as a book-length study, to educate people about neo-paganism and also to reach a broader audience through other media.

The research on which this paper is based was conducted with the support of a Government of Ireland Scholarship in the Humanities and Social Sciences, awarded by the Irish Research Council for the Humanities and Social Sciences. Thanks are also due to my supervisors Dr. Stiofán Ó Cadhla and Prof. Emeritus Gearóid Ó Crualaoich for their help and support. 